\title{
Correlation of interleukin-10 gene haplotype with hepatocellular carcinoma in Taiwan
}

\author{
L.-H. Tseng ${ }^{1}$, M.-T. Lin ${ }^{2,3}$, W.-Y. Shau ${ }^{1}$, W.-C. Lin ${ }^{4}$, F.-Y. Chang ${ }^{1}$, K.-L. Chien ${ }^{1}$, J. A. Hansen ${ }^{3}$, D.-S. Chen ${ }^{1} \&$ \\ P.-J. Chen ${ }^{1}$ \\ 1 Department of Medical Genetics and Internal Medicine, National Taiwan University Hospital, and Graduate Institutes of Clinical Medicine, National \\ Taiwan University, Taipei, Taiwan \\ 2 Institute of Biomedical Sciences, Academia Sinica, Taipei, Taiwan \\ 3 Human Immunogenetics Program, Division of Clinical Research, Fred Hutchinson Cancer Research Center, and Department of Internal Medicine, \\ University of Washington, Seattle, WA, USA \\ 4 Department of Pathology, Albany Medical College, Albany, NY, USA
}

\author{
Key words \\ hepatitis B virus; hepatocellular carcinoma; \\ IL-10; polymorphism

\section{Correspondence} \\ Dr Pei-Jer Chen \\ Graduate Institute of Clinical Medicine \\ College of Medicine \\ National Taiwan University \\ Taipei \\ Taiwan 100 \\ Tel: $886223123456 \times 7072$ \\ Fax: 886223317624 \\ e-mail: peijer@ha.mc.ntu.edu.tw \\ Received 22 June 2005; revised 08 \\ September; re-revised 05 November 2005; \\ accepted 05 November 2005 \\ doi: 10.1111/j.1399-0039.2005.00536.x
}

\begin{abstract}
Polymorphisms in cytokine genes can influence immune responses, inflammation and tissue injury, and may affect the outcome of hepatitis B virus (HBV) infection. We analyzed single nucleotide polymorphisms (SNP) in the interleukin (IL)-10 gene among $344 \mathrm{HBV}$ carriers and 208 patients with hepatocellular carcinoma (HCC). Genotypes and haplotypes were tested for association with HCC. IL-10/ $-592 \mathrm{C} / \mathrm{C}$ genotype was associated with a higher risk for $\mathrm{HCC}$ compared with IL-10/-592 A/C and A/A genotypes [odds ratio (OR): 2.1, 95\% confidence interval (CI): 1.2-3.6]. IL-10/1927 A/A genotype was also associated with a higher risk for HCC compared with IL-10/1927 A/C and C/C genotypes (OR: 1.5, 95\% CI: 1.0-2.2). Haplotype analysis revealed that the homozygosity of the C-A haplotype (defined by SNPs at positions -592 and 1927) of IL-10 gene conveys the highest risk for HCC among HBV carriers compared with the homozygosity for the A-C haplotype (OR: 2.6, 95\% CI: 1.3-4.9). The results demonstrate that IL-10 gene polymorphism can affect the outcome of chronic HBV infection. Further studies are necessary to clarify how variation in the IL-10 gene affects IL-10 function and risk of $\mathrm{HCC}$.
\end{abstract}

\section{Introduction}

Hepatitis B virus (HBV) infection is one of the major infectious diseases prevalent in Taiwan. The prevalence of HBsAg marker in Taiwanese $(>10 \%)$ is higher compared with $0.8 \%$ in Japan, $7.3 \%$ in Korea, and $6 \%$ in Singapore (1). One to three million of the 22-23 million Taiwanese are carriers for HBV. While the majority of infants become chronic HBV carriers following vertical transmission from their mothers, over $90-95 \%$ of adults with acute HBV infection recover with development of lifelong immunity (2). The annual probability of hepatocellular carcinoma (HCC) related to chronic $\mathrm{HBV}$ infection has been estimated to be approximately five in 1000 (3-5).

Cytokines and other immune regulator molecules play a significant role in the pathogenesis of virus-associated chronic hepatitis (6). The activity of individual cytokine genes may be regulated at the level of transcription by certain nucleotide variations in the promoter region, and variations in coding regions may alter the function of the gene product (7). These genetic variations may be associated with susceptibility and clinical severity of human diseases. Recent studies have suggested that the outcome of HBV infection may be affected by host genetic variations (8-15).

Our previous study of 993 hematopoietic stem cell transplants from the Fred Hutchinson Cancer Research Center has shown that an IL-10 promoter single nucleotide polymorphism (SNP) at position -592 is associated with severe grades III-IV acute graft- $v s$-host disease following transplantation from an HLA-identical sibling (16). The other promoter polymorphisms at positions $-3575,-2763$, and 
-1082 , however, are not an independent factor for acute graft- $v s$-host disease. Although the -592 polymorphism was found to have a dominant effect on transplant outcome, the data in that study cannot distinguish whether this SNP at position -592 in the promoter region or an extended sequence in the entire IL-10 gene accounts for the observed functional effect. In the current study, genotypes of IL-10/-592 and other SNPs downstream to the initiation site of transcription were determined among HBV carriers and patients with HCC in Taiwan. The results showed that a haplotype of IL-10 gene influenced the risk of developing HCC.

\section{Materials and methods}

\section{Study population}

The study population consisted of 344 serum HBV surface antigen-positive Taiwanese with HCC excluded using ultrasonography ( $\mathrm{HBsAg}^{+}$carriers), $208 \mathrm{HBsAg}^{+}$patients with pathologically diagnosed HCC, and 184 healthy control individuals who were consecutively enrolled without the identification of HBV infection status before the study. The median age (range) was 53 (25-77), 50 (21-81), and 55 (23-85) years for the control populations, $\mathrm{HBsAg}^{+}$carrier, and patients with $\mathrm{HCC}$, respectively. All the studied populations gave consent according to a protocol approved by the National Taiwan University Hospital Institutional Review Board.

\section{Haplotype-tagging SNPs in IL-10 gene}

The immense volume of SNP data presents challenge for studies of the association between genetic variations and human diseases. It is not an efficient strategy to assay all the existing SNPs. The UW-FHCRC Variation Discovery Resource has developed an algorithm to select the maximally informative set of tagSNP or htSNP based on the linkage disequilibrium (LD) statistic $(17,18)$. The IdSelect program was used to analyze the pattern of LD between SNPs in a locus or a selected gene (18). SNPs in the selected gene are grouped into one or more 'bins' according to a threshold level of LD as measured by $\mathrm{r}^{2}$. Selection of one htSNP from each bin can encompass all the informative SNPs for that gene. The UW-FHCRC Variation Discovery Resource has identified SNPs in the immune regulatory genes including IL-10 among 24 individuals of African descent and 23 individuals of European descent (17). Although the selection of haplotype-tagging SNPs (htSNPs) for individuals of European descent may not perfectly reflect all the informative SNPs in Taiwanese, this approach provides a reasonable approach to identify possible informative SNPs in the IL-10 gene in Taiwanese.

Analysis of LD in the IL-10 gene among individuals of European descent identifies six bins each with at least one informative htSNP that has a minor allele frequency of greater than $5 \%$ : bin $1,46-50 \%$ (positions 1498,1833 , $3166,5016,6049$, and 6570 of accession number AF418271); bin 2: 22-26\% (positions 245, 472, 1568, 2018, 2234, and 2646 of AF418271); bin 3: 22-23\% (4467 and 6976), bin 4: 19-20\% (2767 and 5351); bin 5: 7\% (213 and 3582); and bin 6: 10\% (1927). IL-10/-592 (position 472 of accession number AF418271) along with the other five SNPs was grouped in bin 2. Genotypes of IL-10/-592 and one htSNP selected from each of bins $1,3,4,5$, and 6 were determined among 48 Taiwanese controls and 24 Caucasian CEPH cell lines obtained from International Histocompatibility Working Group cytokine gene polymorphism reference panel (www.ihwg.org/components/ cytokine/cytover.htm).

\section{Genotyping of SNP}

Genotyping was performed using high-throughput MALDI-TOF mass spectrometry (Sequenom, San Diego, CA) $(19,20)$. Briefly, uniplex polymerase chain reaction (PCR) was carried out by the forward and reverse primers. After primer extension, the purified DNA fragments were spotted onto a 384-element silicon chip and analyzed in the Bruker Biflex III MALDI-TOF SpectroREADER mass spectrometer. The resulting spectra were processed with SpectroTYPER (Sequenom). Genotyping using mismatched PCR/restriction fragment length polymorphism (PCR/RFLP) (21) was also performed among the 24 $\mathrm{CEPH}$ cell lines to compare with those determined using MALDI-TOF mass spectrometry.

\section{Statistic analysis}

Hardy-Weinberg equilibrium of alleles at individual loci was assessed using $\chi^{2}$ goodness-of-fit statistics. Haplotype frequencies and $\chi^{2}$ test for LD among pairs of alleles were calculated using the Estimating Haplotype frequencies (EH) program from Rockefeller University (fttp:/linkage. rockefeller.edu/software/eh) as described previously $(16,22)$. The difference in the genotype frequencies and haplotype frequencies was compared between $\mathrm{HBV}$ carriers and patients with $\mathrm{HCC}$ to elucidate the risk for $\mathrm{HCC}$ among HBV carriers. Odds ratio (OR) and 95\% confidence interval $(\mathrm{CI})$ were calculated using sas program. All $P$-values were two sided. The significance level adjusted for Bonferroni correction was calculated by dividing original alpha level (0.05) with number of statistic testing.

\section{Results}

\section{Genotyping of IL-10 htSNPs}

Genotypes of IL-10/-592 (bin 2) and one htSNP selected from each of the bins $1,3,4,5$, and 6 were determined among 48 Taiwanese and 24 Caucasian CEPH cell lines 
(Table 1). The allele frequencies of the $24 \mathrm{CEPH}$ cell lines were similar to those reported among the 23 European descents by UW-FHCRC Variation Discovery Resource.

The genotyping of IL-10/-592 and IL-10/1927 among the 24 CEPH cell lines by MALDI-TOF mass spectrometry was consistent with those by a Bsil-basedmismatched PCR/RFLP (21) and a MwoI-based mismatched PCR/RFLP, respectively (unpublished). The allele frequencies of the -592 SNP among the $24 \mathrm{CEPH}$ cell lines were similar to those reported previously, $76 \%$ for the $\mathrm{C}$ allele and $24 \%$ for the A allele $(23,24)$. In contrast to Caucasians, the minor allele of the IL-10/-592 $\mathrm{SNP}$ in Taiwanese controls was the $\mathrm{C}$ allele with a frequency of $31 \%$. The allele frequencies of 1927 polymorphism among the 24 Caucasian CEPH cell lines were also the same as those reported previously, $10 \%$ for $\mathrm{C}$ allele and $90 \%$ for A allele (17). Allele frequency of 1927 among control population in Taiwanese was $46 \%$ for C allele and $54 \%$ for $\mathrm{A}$ allele. In Taiwanese, the minor allele frequency was $5 \%$ or less for the other four htSNPs (bins 1, 3, 4, and 5). Therefore, only SNPs at positions IL-10/ 1927 (rs 3021094) and IL-10/-592 (rs 1800872) were selected for further study among larger scale populations.

\section{Genotypes of IL-10/-592 and IL-10/1927 polymorphisms among $\mathrm{HBsAg}^{+}$carriers and patients with HCC}

The frequencies of the IL-10/-592 C/C genotype (homozygosity for the $\mathrm{C}$ allele) were 10,8 , and $15 \%$ for the control population, $\mathrm{HBsAg}^{+}$carriers and patients with HCC, respectively (Table 2). All the genotypes were in Hardy-Weinberg equilibrium. The frequencies of the IL-10/1927 A/A genotype were 26, 22, and $30 \%$ for the control population, $\mathrm{HBsAg}^{+}$carriers and patients with HCC, respectively (Table 2 ).

\section{IL-10 genotype and HCC}

IL-10/-592 genotypes were compared between the HBV carriers and patients with $\mathrm{HCC}$ to evaluate the influence of IL-10 gene polymorphism on the development of HCC. The absence of IL-10/-592 A allele (C/C genotype) was significantly associated with an increased risk for $\mathrm{HCC}$ compared with the presence of A allele $(\mathrm{A} / \mathrm{C}$ and $\mathrm{A} / \mathrm{A}$ genotypes) (OR: 2.1, 95\% CI: $1.2-3.6, P$-value $=0.009$, adjusted significance level by Benoferoni correction $=0.025$ ). Similarly, the IL-10/1927 A/A genotype was also associated with a higher risk for HCC (OR: 1.5, 95\% CI: 1.0-2.2, $P$-value $=0.04$, adjusted significance level by Benoferoni correction $=0.025$ ).

\section{IL-10 haplotype and HCC}

Previous studies have identified at least two clusters of polymorphisms in the $5^{\prime}$ flanking region of the IL-10 gene at positions $-1082,-819$, and -592 and at positions -3575 and $-2763(25,26)$. These five SNPs comprised six distinct major haplotypes among Caucasians $(16,26)$. In the previous study, we demonstrated that -592 has a

Table 1 Allele frequencies of htSNPs in the interleukin (IL)-10 gene among Caucasians, Taiwanese, and individuals of African descents

\begin{tabular}{|c|c|c|c|c|}
\hline \multirow[b]{2}{*}{ Position $^{a}$ (bin number) } & \multirow[b]{2}{*}{ Allele } & \multicolumn{3}{|l|}{ Allele frequencies (\%) } \\
\hline & & Caucasian $(\mathrm{n}=24)^{\mathrm{b}}$ & Taiwanese $(n=48)$ & African descents $(n=24)^{c}$ \\
\hline \multirow[t]{2}{*}{$3166(\operatorname{bin} 1)^{d}$} & C & $52(54)$ & 95 & 65 \\
\hline & $\mathrm{G}$ & $48(46)$ & 5 & 35 \\
\hline \multirow[t]{2}{*}{ IL-10/-592 (bin 2) } & $A$ & $21(24)$ & 69 & 50 \\
\hline & C & $79(76)$ & 31 & 50 \\
\hline \multirow[t]{2}{*}{6976 (bin 3) } & $\mathrm{C}$ & $79(78)$ & 98 & 91 \\
\hline & $\mathrm{T}$ & $21(22)$ & 2 & 9 \\
\hline \multirow[t]{2}{*}{5351 (bin 4) } & $A$ & $84(79)$ & 99 & 85 \\
\hline & $\mathrm{G}$ & $14(21)$ & 1 & 15 \\
\hline \multirow[t]{2}{*}{3582 (bin 5) } & $\mathrm{C}$ & $10(7)$ & 0 & 0 \\
\hline & $\mathrm{T}$ & $90(93)$ & 100 & 100 \\
\hline \multirow[t]{2}{*}{1927 (bin 6) } & $A$ & $90(90)$ & 54 & 94 \\
\hline & $\mathrm{C}$ & $10(10)$ & 46 & 6 \\
\hline
\end{tabular}

\footnotetext{
aPosition of accession number AF418271. One htSNP was selected from each bin of IL-10 gene polymorphisms according to the linkage disequilibrium analysis available from UW-FHCRC Variation Discovery Resource (http://pga.gs.washington.edu).

${ }^{b}$ Twenty-four Caucasian CEPH cell lines established from unrelated individuals. Number in the parenthesis indicates data from 23 individuals of European descent (UW-FHCRC Variation Discovery Resource).

'Data from 24 individuals of African descent (UW-FHCRC Variation Discovery Resource).

${ }^{\mathrm{d}}$ Genotyping of IL-10/-1082 among the 24 CEPH cell lines indicated that the -1082 SNP belongs to bin 1 . The minor allele frequency of IL-10/-1082 among Taiwanese controls is $5 \%$.

eIL-10/-592 (position 472 of AF418271) belongs to bin 2. In this study, -592 instead of 472 was used.
} 
Table 2 Interleukin (IL)-10/-592 and IL-10/1927 genotypes in Taiwanese

\begin{tabular}{lccr}
\hline Genotype & Controls $^{\mathrm{a}}$ & $\mathrm{HBsAg}^{+}$carriers $^{\mathrm{b}}$ & $\mathrm{HCC}^{\mathrm{C}}$ \\
\hline IL-10/-592 & & & \\
A/A & $90(49 \%)$ & $169(49 \%)$ & $93(45 \%)$ \\
A/C & $75(41 \%)$ & $148(43 \%)$ & $84(40 \%)$ \\
C/C & $19(10 \%)$ & $27(8 \%)$ & $31(15 \%)$ \\
IL-10/1927 & & & \\
A/A & $48(26 \%)$ & $76(22 \%)$ & $62(30 \%)$ \\
A/C & $96(52 \%)$ & $181(53 \%)$ & $100(49 \%)$ \\
C/C & $39(21 \%)$ & $86(25 \%)$ & $44(21 \%)$ \\
\hline
\end{tabular}

$\mathrm{HCC}$, hepatocellular carcinoma; HBV, hepatitis B virus.

${ }^{a}$ Control population consisted of 184 consecutively enrolled Taiwanese whose status of HBV infection was not known before study.

${ }^{b} \mathrm{HBV}$ carriers without clinical evidence of HCC $(n=344)$.

${ }^{\mathrm{c}} \mathrm{HBs} \mathrm{Ag}^{+}$patients with pathologically diagnosed HCC $(n=208)$.

dominant effect on the outcome of hematopoietic cell transplantation and is a marker for T-C-A-T-A haplotype defined by five polymorphisms at positions $-3575,-2763$, $-1082,-819$, and -592 . In the current study, the analysis of the control population showed that $-592 * \mathrm{C}$ allele was in high degree of LD with the $1927^{*} \mathrm{~A}$ allele (Table 3). The estimated frequencies of the C-A haplotype (defined by -592 and 1927) among the control population, $\mathrm{HbsAg}^{+}$ carriers, and patients with HCC were 31,28 , and $35 \%$, respectively.

To determine whether the development of HCC might be more closely associated with one or more distinct haplotypes than with individual polymorphism, we calculated the risk for HCC among the nine groups stratified according to the IL-10/-592 and IL-10/1927 genotypes. Homozygosity for the C-A haplotype (IL-10/-592 C/C genotype and IL-10/1927 A/A genotype) conveyed a significant highest risk for HCC (OR: 2.6; 95\% CI: 1.3-4.9; $P$-value $=0.004)$ compared with the homozygosity for the A-C haplotype (IL-10/-592 A/A genotype and IL-10/ 1927 C/C genotype) (Table 4).

\section{Discussion}

In this study, we demonstrated that IL-10 gene polymorphism had a significant impact on the outcome of HBV infection. The IL-10/-592 C/C genotype and the IL-10/1927 A/A genotype were associated with a higher

Table 3 Linkage disequilibrium between interleukin (IL)-10/-592 and IL-10/1927

\begin{tabular}{|c|c|c|c|c|c|c|c|}
\hline \multirow[b]{2}{*}{ Population } & \multicolumn{4}{|c|}{ Haplotype frequencies ${ }^{a}$} & \multicolumn{3}{|c|}{ Linkage disequilibrium } \\
\hline & $A-C$ & $A-A$ & $\mathrm{C}-\mathrm{C}$ & C-A & $D^{\prime}$ & $\chi^{2}$ & $P$-value \\
\hline Control & 0.48 & 0.22 & $<0.01$ & 0.31 & -0.906 & 122.08 & $<0.05$ \\
\hline HBsAg carrier & 0.50 & 0.20 & 0.01 & 0.28 & -0.981 & 169.11 & $<0.05$ \\
\hline Hepatocellular carcinoma & 0.45 & 0.20 & 0.01 & 0.35 & -0.808 & 136.42 & $<0.05$ \\
\hline
\end{tabular}

${ }^{a}$ Defined by polymorphisms at positions IL-10/-592 and IL-10/1927.

Table 4 Interleukin (IL)-10 -592/1927 haplotype and risk of hepatocellular carcinoma

\begin{tabular}{|c|c|c|c|c|c|}
\hline \multirow[b]{2}{*}{ Genotype $(-592,1927)$} & \multirow[b]{2}{*}{ Assigned haplotype ${ }^{a}$} & \multirow[b]{2}{*}{$\mathrm{HBsAg}^{+}$carriers } & \multirow[b]{2}{*}{$\mathrm{HCC}$} & \multicolumn{2}{|l|}{ Risk for $\mathrm{HCC}^{\mathrm{b}}$} \\
\hline & & & & OR $(95 \% \mathrm{CI})^{\mathrm{b}}$ & $P$-value ${ }^{d}$ \\
\hline $\mathrm{A} / \mathrm{A}, \mathrm{C} / \mathrm{C}$ & $A-C / A-C$ & $83(24 \%)$ & $42(20 \%)$ & Reference & \\
\hline $\mathrm{A} / \mathrm{A}, \mathrm{A} / \mathrm{C}$ & A-A/A-C & $71(21 \%)$ & $38(18 \%)$ & $1.1(0.6-1.8)$ & 0.84 \\
\hline $\mathrm{A} / \mathrm{A}, \mathrm{A} / \mathrm{A}$ & A-A/A-A & $15(4 \%)$ & $11(5 \%)$ & $1.4(0.6-3.4)$ & 0.40 \\
\hline $\mathrm{A} / \mathrm{C}, \mathrm{C} / \mathrm{C}$ & $\mathrm{A}-\mathrm{C} / \mathrm{C}-\mathrm{C}$ & $1(0 \%)$ & $2(1 \%)$ & $N / A^{c}$ & $N / A^{c}$ \\
\hline $\mathrm{A} / \mathrm{C}, \mathrm{A} / \mathrm{C}$ & $A-C / C-A^{a}$ & $109(32 \%)$ & $62(30 \%)$ & $1.1(0.7-1.8)$ & 0.64 \\
\hline $\mathrm{A} / \mathrm{C}, \mathrm{A} / \mathrm{A}$ & A-A/C-A & $37(11 \%)$ & $20(10 \%)$ & $1.1(0.6-2.1)$ & 0.84 \\
\hline $\mathrm{C} / \mathrm{C}, \mathrm{C} / \mathrm{C}$ & $\mathrm{C}-\mathrm{C} / \mathrm{C}-\mathrm{C}$ & $2(1 \%)$ & $0(0 \%)$ & $N / A^{c}$ & $N / A^{c}$ \\
\hline $\mathrm{C} / \mathrm{C}, \mathrm{A} / \mathrm{C}$ & C-A/C-C & $1(0 \%)$ & $0(0 \%)$ & $N / A^{c}$ & $N / A^{c}$ \\
\hline $\mathrm{C} / \mathrm{C}, \mathrm{A} / \mathrm{A}$ & C-A/C-A & $24(7 \%)$ & $31(15 \%)$ & $2.6(1.3-4.9)$ & 0.004 \\
\hline
\end{tabular}

$\mathrm{HCC}$, hepatocellular carcinoma; $\mathrm{Cl}$, confidence interval; OR, odds ratio.

${ }^{a}$ Assumed very low frequency of C-C haplotype (1\% in this study).

${ }^{b}$ Odds ratios for hepatocellular carcinoma were calculated using $\mathrm{HBsAg}^{+}$carriers as the control and homozygosity for the A-C haplotype as the reference group. Homozygosity for the C-A haplotype (IL-10/-592 C/C genotype and IL-10/1927 A/A genotype) is associated with a significant higher risk for HCC compared with the remaining eight groups [OR: $2.4 ; 95 \% \mathrm{Cl}: 1.3-4.1 ; P$-value: 0.003$]$.

${ }^{c}$ Not analyzed due to very low case number.

${ }^{\mathrm{d}}$ Adjusted significance level by Benoferoni correction $=0.006$. 
risk for $\mathrm{HCC}$ among HBV carriers. Haplotype analysis revealed that the IL-10/-592*C allele is in high LD with the IL-10/1927*A allele, and the homozygosity for the C-A haplotype carries the highest risk for the development of HCC.

Cytokines play an essential role on the pathogenesis of virus-associated hepatitis (6). Clearance of hepatitis viruses following acute infection is associated with a vigorous cytotoxic T-cell response, partially mediated and augmented through inhibition of viral replication and gene expression by the proinflammatory and Th1 cytokines (27-32). IL-10 is a potent suppressor of proinflammatory, and Th1 cytokine production $(33,34)$ therefore may compromise the host immune response to acute viral infection $(6,35,36)$.

If patients cannot eradicate the viruses and become HBV carriers, persistent antiviral cytotoxic T-lymphocyte response, however, may induce intrahepatic inflammation and subsequently the development of cirrhosis and HCC (6). The degree of tissue inflammation and fibrosis caused by persistent viral hepatitis is associated with the enhanced intrahepatic expression of the proinflammatory and Th1 cytokines (37-39). IL-10 may attenuate these inflammatory responses and reduce liver injury. Deficit of endogenous IL-10 production can potentiate liver fibrosis following a variety of experimental hepatotoxicity models (40-44). Administration of IL-10 reduces intrahepatic inflammation and fibrosis in patients with chronic hepatitis $\mathrm{C}$ infection (45).

Previous studies have reported that IL-10 promoter $-1082 * \mathrm{G}$ allele or $G-C-C$ haplotype (defined by three SNPs at positions of $-1082,-819$, and -592 ) is associated with increased IL-10 production and $A-T-A$ haplotype is generally assumed to be a lower IL-10 responder $(24,25)$. Miyazoe et al. (11) have shown higher frequency of IL-10/-592 C/C genotype among $\mathrm{HBsAg}^{+}$patients with chronic progressive liver disease compared with the asymptomatic HBV carriers. The authors concluded that the high IL-10-producing $-592 * \mathrm{C}$ allele was associated with a lower overall immune defense and therefore progressive chronic liver disease. Shin et al. reported that the IL-10/-592 C/C genotype was associated with an increased risk of $\mathrm{HCC}$, which was confirmed in the current study (13). These authors also proposed that the higher IL-10 level among HBV carriers with IL-10/-592 C/C genotype may impair immune defense and contribute to the development of HCC.

Conflicting results have been reported regarding the genetic control of IL-10 production (24-26, 46). Keijsers et al. and Gibson et al. reported that the $G-C-C(-1082 /$ $-819 /-592)$ haplotype and $A-A-G-C-C$ haplotype (defined by five SNPs at positions $-3575,-2763,-1082,-819$, and -592$)$ were associated with a lower IL-10 production $(26,46)$. Previous studies have shown that IL-10 may attenuate graft- $v s$-host disease and induce tolerance following hematopoietic cell transplantation (47, 48). Endogenous IL-10 production soon after transplantation has been shown to facilitate the suppression of alloimmune response $(49,50)$. We and others have previously shown that $-592 * \mathrm{C}$ was a marker for a higher risk of severe graft$v s$-host disease $(16,51)$, supporting the hypothesis that the $-592 * \mathrm{C}$ allele or $G-C-C$ haplotype is a marker for lower IL-10 production.

The association between IL-10/-592 C/C genotype and risk of $\mathrm{HCC}$ in the current study among Taiwanese is similar to findings reported among Korean (14), but our interpretations differ. Our data along with results from other studies in Asian population $(11,14)$ suggest that IL-10/ $-592 *$ C allele may be a marker for lower IL-10 production. This assumption is more consistent with the generally accepted role of IL-10 as a mediator that inhibits immune response and inflammation therefore ameliorating hepatic inflammation and reducing the risk of subsequent fibrosis and HCC among chronic hepatitis carriers.

Our results show that IL-10 gene polymorphism is associated with outcome of HBV infection. Homozygosity for the C-A haplotype (defined by IL-10 -592 and 1927) conveys a higher risk for HCC among HBV carriers. The results, however, do not exclude the possibility that haplotypes of IL-10 gene defined by the other hpSNPs of Taiwanese or Asian population may be a better marker for risk of HCC. Precise insight into the mechanism underlying this genetic association could provide a rationale for new strategies and approaches to reduce the intensity of the inflammatory response and risk of subsequent cirrhosis and HCC among HBV carriers. Further studies are necessary to clarify how variation in the IL-10 gene regulates IL-10 production.

\section{Acknowledgments}

This work has been supported by grants NSC93-3112-B002-004, NSC93-2314-B-002-226 and IBMS-CRC93-T02, Taiwan, and NIH grants AI33484, AI49213, CA18029, and CA15704, USA. The authors thank the members of the Department of Medical Research at National Taiwan University Hospital and National Genotyping Center at Academia Sinica for support in SNP genotyping.

\section{References}

1. Merican I, Guan R, Amarapuka D et al. Chronic hepatitis B virus infection in Asian countries. $J$ Gastroenterol Hepatol 2000: 15: 1356-61.

2. McQuillan GM, Townsend TR, Fields HA, Carroll M, Leahy M, Polk BF. Seroepidemiology of hepatitis B virus infection in the United States: 1976 to 1980. Am J Med 1989: 87: $5 \mathrm{~S}-10 \mathrm{~S}$. 
3. Chen PJ, Chen DS. Hepatitis B virus infection and hepatocellular carcinoma: molecular genetics and clinical perspectives. Semin Liver Dis 1999: 19: 253-62.

4. Di Bisceglie AM, Carithers RL Jr, Gores GJ. Hepatocellular carcinoma. Hepatology 1998: 28: 1161-5.

5. Yang HI, Lu SN, Liaw YF et al. Hepatitis B e antigen and the risk of hepatocellular carcinoma. $N$ Engl J Med 2002: 347: 168-74.

6. Koziel MJ. Cytokines in viral hepatitis. Semin Liver Dis 1999: 19: $157-69$.

7. Bidwell J, Keen L, Gallagher G et al. Cytokine gene polymorphism in human disease: on-line databases. Genes Immun 1999: 1: 3-19.

8. Yu MW, Gladek-Yarborough A, Chiamprasert S, Santella RM, Liaw YF, Chen CJ. Cytochrome P450 2E1 and glutathione S-transferase M1 polymorphisms and susceptibility to hepatocellular carcinoma. Gastroenterology 1995: 109: 1266-73.

9. Hohler T, Kruger A, Gerken G, Schneider PM, Meyer zum Buschenefelde KH, Rittner CA. Tumor necrosis factor-alpha (TNF-alpha) promoter polymorphism is associated with chronic hepatitis B infection. Clin Exp Immunol 1998: 111: 579-82.

10. Thursz M. Genetic susceptibility in chronic viral hepatitis. Antiviral Res 2001: 52: 113-6.

11. Miyazoe S, Hamasaki K, Nakata $\mathrm{K}$ et al. Influence of interleukin-10 gene promoter polymorphisms on disease progression in patients chronically infected with hepatitis B virus. Am J Gastroenterol 2002: 97: 2086-92.

12. Yu MW, Yang YC, Yang SY et al. Androgen receptor exon $1 \mathrm{CAG}$ repeat length and risk of hepatocellular carcinoma in women. Hepatology 2002: 36: 156-63.

13. Yeh SH, Chang CF, Shau WY et al. Dominance of functional androgen receptor allele with longer $\mathrm{CAG}$ repeat in hepatitis B virus-related female hepatocarcinogenesis. Cancer Res 2002: 62: 4346-51.

14. Shin HD, Park BL, Kim LH et al. Interleukin 10 haplotype associated with increased risk of hepatocellular carcinoma. Hum Mol Genet 2003: 12: 901-6.

15. Wang Y, Kato N, Hoshida $Y$ et al. Interleukin-1beta gene polymorphisms associated with hepatocellular carcinoma in hepatitis C virus infection. Hepatology 2003: 37: 65-71.

16. Lin MT, Storer B, Martin PJ et al. Relation of an interleukin-10 promoter polymorphism to graft-versus-host disease and survival after hematopoietic-cell transplantation. $N$ Engl $J$ Med 2003: 349: 2201-10.

17. SeattleSNPs, NHLBI Program for Genomic Application, UW-FHCRC, Seattle, WA (http://pga.mbt.washington.edu) [December 2002].

18. Carlson CS, Eberle MA, Rieder MJ, Yi Q, Kruglyak L, Nickerson DA. Selecting a max informative set of singlenucleotide polymorphisms for association analysis using disequilibrium. Am J Hum Genet 2004: 74: 106-20.

19. Gabriel SB, Schaffner SF, Nguyen H et al. The structure of haplotype blocks in the human genome. Science 2002: 296: 2225-9.

20. Tang K, Fu DJ, Julien D, Braun A, Cantor CR, Koster H. Chip-based genotyping by mass spectrometry. Proc Natl Acad Sci USA 1999: 6: 10016-20.
21. Tseng LH, Chen PJ, Lin MT et al. Simultaneous genotyping of single nucleotide polymorphisms in the IL-6, IL-10, TNF $\alpha$ and TNF $\beta$ genes. Tissue Antigens 2002: 59: 280-6.

22. Hartl DL, Clark AG. Organization of genetic variation. In: Principles of Population Genetics, 3rd edn. Sunderland, MA: Sinauer 1997, 71-109.

23. Koss K, Satsangi J, Fanning GC, Welsh KI, Jewell DP. Cytokine (TNF $\alpha, \mathrm{LT} \alpha$ and IL-10) polymorphisms in inflammatory bowel diseases and normal controls: differential effects on production and allele frequencies. Genes Immun 2000: 1: 185-90.

24. Crawley E, Kay R, Sillibourne J, Patel P, Hutchinson I, Woo P. Polymorphic haplotypes of the interleukin-10 5' flanking region determine variable interleukin-10 transcription and are associated with particular phenotypes of juvenile rheumatoid arthritis. Arthritis Rheum 1999: 42: 1101-8.

25. Turner DM, Williams DM, Sankaran D, Lazarus M, Sinnott PJ, Hutchinson IV. An investigation of polymorphism in the interleukin-10 gene promoter. Eur J Immunogenet 1997: 24: 1-8.

26. Gibson AW, Edberg JC, Wu J, Westendorp RG, Huizinga TW, Kimberly RP. Novel single nucleotide polymorphisms in the distal IL-10 promoter affect IL-10 production and enhance the risk of systemic lupus erythematosus. $J$ Immunol 2001: 166: 3915-22.

27. Guidotti LG, Guilhot S, Chisari FV. Interleukin-2 and alpha/beta interferon down-regulate hepatitis B virus gene expression in vivo by tumor necrosis factor-dependent and -independent pathways. J Virol 1994: 68: 1265-70.

28. Guidotti LG, Ando K, Hobbs MV et al. Cytotoxic T lymphocytes inhibit hepatitis B virus gene expression by a noncytolytic mechanism in transgenic mice. Proc Natl Acad Sci USA 1994: 91: 3764-8.

29. Guidotti LG, Ishikawa T, Hobbs MV, Matzke B, Schreiber R, Chisari FV. Intracellular inactivation of the hepatitis B virus by cytotoxic T lymphocytes. Immunity 1996: 4: 25-36.

30. Romero R, Lavine JE. Cytokine inhibition of the hepatitis B virus core promoter. Hepatology 1996: 23: 17-23.

31. Penna A, Del Prete G, Cavalli A et al. Predominant T-helper 1 cytokine profile of hepatitis B virus nucleocapsid-specific T cells in acute self-limited hepatitis B. Hepatology 1997: 25: 1022-7.

32. Rico MA, Quiroga JA, Subira D et al. Hepatitis B virusspecific T-cell proliferation and cytokine secretion in chronic hepatitis B e antibody-positive patients treated with ribavirin and interferon alpha. Hepatology 2001: 33: 295-300.

33. Fiorentino DF, Zlotnik A, Mosmann TR, Howard M, O'Garra A. IL-10 inhibits cytokine production by activated macrophages. J Immunol 1991: 147: 3815-22.

34. Ralph P, Nakoinz I, Sampson-Johannes A et al. IL-10, T lymphocyte inhibitor of human blood cell production of IL-1 and tumor necrosis factor. J Immunol 1992: 148: 808-14.

35. Moore KW, O'Garra A, de Waal Malefyt R, Vieira P, Mosmann TR. Interleukin-10. Annu Rev Immunol 1993: 11: 165-90.

36. Cacciarelli TV, Martinez OM, Gish RG, Villanueva JC, Krams SM. Immunoregulatory cytokines in chronic hepatitis $C$ virus infection: pre- and post-treatment with interferon- $\alpha$. Hepatology 1996: 24: 6-9. 
37. Barnaba V, Franco A, Paroli M et al. Selective expansion of cytotoxic $\mathrm{T}$ lymphocytes with a $\mathrm{CD} 4{ }^{+} \mathrm{CD} 56^{+}$surface phenotype and a $\mathrm{T}$ helper type 1 profile of cytokine secretion in the liver of patients chronically infected with Hepatitis B virus. J Immunol 1994: 152: 3074-87.

38. Napoli J, Bishop GA, McGuinness PH, Painter DM, McCaughan GW. Progressive liver injury in chronic hepatitis $\mathrm{C}$ infection correlates with increased intrahepatic expression of Th1-associated cytokines. Hepatology 1996: 24: 759-65.

39. Friedman SL. Cytokines and fibrogenesis. Semin Liver Dis 1999: 19: 129-40.

40. Arai T, Hiromatsu K, Kobayashi N et al. IL-10 is involved in the protective effect of dibutyryl cyclic adenosine monophosphate on endotoxin-induced inflammatory liver injury. J Immunol 1995: 155: 5743-9.

41. Louis H, Le Moine O, Peny MO et al. Production and role of interleukin-10 in concanavalin A-induced hepatitis in mice. Hepatology 1997: 25: 1382-9.

42. Thompson KC, Trowern A, Fowell A et al. Primary rat and mouse hepatic stellate cells express the macrophage inhibitor cytokine interleukin-10 during the course of activation In vitro. Hepatology 1998: 28: 1518-24.

43. Thompson K, Maltby J, Fallowfield J, McAulay M, Millward-Sadler H, Sheron N. Interleukin-10 expression and function in experimental murine liver inflammation and fibrosis. Hepatology 1998: 28: 1597-606.

44. Nagaki M, Tanaka M, Sugiyama A, Ohnishi H, Moriwaki H. Interleukin-10 inhibits hepatic injury and tumor necrosis factor-alpha and interferon-gamma mRNA expression induced by staphylococcal enterotoxin B or lipopolysaccharide in galactosamine-sensitized mice. J Hepatol 1999: 31: 815-24.

45. Nelson DR, Lauwers GY, Lau JY, Davis GL. Interleukin 10 treatment reduces fibrosis in patients with chronic hepatitis C: a pilot trial of interferon nonresponders. Gastroenterology 2000: 118: 655-60.

46. Keijsers V, Verweij CL, Westendorp RGJ, Breedveld FC, Huizinga TWJ. IL-10 polymorphisms in relation to production and rheumatoid arthritis. Arthritis Rheum 1997: 40: S179.

47. Groux H, Bigler M, de Vries JE, Roncarolo MG. Interleukin-10 induces a long-term antigen-specific anergic state in human CD4 ${ }^{+}$T cells. J Exp Med 1996: 184: 19-29.

48. Krenger W, Hill GR, Ferrara JL. Cytokine cascades in acute graft-versus-host disease. Transplantation 1997: 64: 553-8.

49. Bacchetta R, Bigler M, Touraine JL et al. High levels of interleukin 10 production in vivo are associated with tolerance in SCID patients with HLA mismatched hematopoietic stem cells. J Exp Med 1994: 179: 493-502.

50. Holler E, Roncarolo MG, Hintermeier-Knabe R et al. Prognostic significant of increased IL-10 production in patients prior to allogeneic bone marrow transplantation. Bone Marrow Transplant 2000: 25: 237-41.

51. Socie G, Loiseau P, Tamouza R et al. Both genetic and clinical factors predict the development of graft-versus-host disease after allogeneic hematopoietic stem cell transplantation. Transplantation 2001: 72: 699-706. 
Copyright of Tissue Antigens is the property of Blackwell Publishing Limited and its content may not be copied or emailed to multiple sites or posted to a listserv without the copyright holder's express written permission. However, users may print, download, or email articles for individual use. 